\title{
PRODUCTIVITY MONITORING OF CONSTRUCTION ACTIVITIES USING DIGITAL TECHNOLOGIES: A LITERATURE REVIEW
}

\author{
Amanda da S. Barbosa ${ }^{1}$ and Dayana B. $\operatorname{Costa}^{2}$
}

\begin{abstract}
Although the engineering and construction sector is one of the largest in the world economy, it has historically been characterized by a low level of productivity and innovation. Traditional methods for productivity assessment at construction sites, despite being effective, are time-consuming and based on manual data collection and direct observation of activities on-site, which hampers the obtaining of reliable and up-to-date information of activities productivity. To contribute to future research in this area, this study aims to identify and analyze the main existing methods for measuring, analyzing, and improving productivity at construction sites using digital technologies, based on a systematic literature review. A total of 35 papers dated from 2010 to 2021 were selected using Scopus, ASCE Library, and Web of Science databases. Results show that technologies based on computer vision and sensors are the most used by researchers, being able to automate data collection for work sampling and activity analysis, measure inputs, outputs, and cycle times, and monitor factors that can influence workers' productivity. These technologies also have the potential to assist in the development of data collection methods for the assessment of productivity, ergonomics, and worker wellbeing. This integration, despite valuable, has been little explored in the literature.
\end{abstract}

\section{KEYWORDS}

Waste, flow, time compression, construction productivity, digital technologies.

\section{INTRODUCTION}

According to a McKinsey report (Ribeirinho et al. 2020), construction is one of the biggest industries in the world, being responsible for $13 \%$ of the global Gross Domestic Product, and yet, even when outside of crises, it does not perform well. Improving the effectiveness of production control has attracted the interest of researchers and lean construction practitioners over the years. In lean construction, production activities are improved continuously with respect to waste and value (Koskela 1992).

With the advent of Industry 4.0, companies have been channelling their efforts to achieve superior performance by advancing levels of automation and interconnectivity (Tortorella et al. 2019). With the incorporation of Industry 4.0 technologies, process

Civil Engineer, Master's Student, Graduate Program in Civil Engineering, Federal University of Bahia (UFBA), Brazil, barbosa.amanda@ufba.br, orcid.org/0000-0002-1982-6633

2 Associate Professor, Engineering School, Department of Structural and Construction Engineering, Graduate Program in Civil Engineering, Federal University of Bahia (UFBA), Brazil, dayanabcosta@ufba.br, orcid.org/0000-0002-1457-6401 
stability increases and potential issues that jeopardise delivering according to customers' needs can be anticipated (Tortorella et al. 2019). According to Zhao et al. (2019), the use of digital technologies to measure waste on worker, subcontractor and project level could provide significant benefits to an industry plagued with poor productivity. To contribute to future research in this area, this study aims to identify and analyze the main existing methods for measuring, analyzing, and improving productivity on construction sites using digital technologies for automated data collection, based on a systematic literature review.

\section{PRODUCTIVITY MONITORING IN CONSTRUCTION}

Definitions of productivity range from industry-wide economic parameters to the measurement of crews and individuals, and each of these measures has its unique purpose (Thomas et al. 1990). According to Thomas et al. (1990), at the project site, contractors are often interested in labor productivity, which can be expressed as the ratio between outputs expressed in specific physical units and inputs expressed in man-hours.

Work sampling, as a technique used to indirectly assess productivity, consists of observing the activities at regular intervals and categorizing them into different work categories to evaluate how time is utilized (Liou and Borcherding 1986). Each observation records what is happening at that instant, and the technique is based upon statistical sampling theory (Thomas et al. 1990). Compared to work sampling, the activity analysis technique includes more detailed observations, provides a more descriptive assessment of the effectiveness of the utilization of workers' time, and can continuously identify the areas for productivity improvements (Cheng et al. 2013).

Regarding the calculation of productivity rates for machinery performing cyclic activities, it is first necessary to estimate the cycle times (Sabillon et al. 2020). On earthmoving activities, the soil amount, which can be estimated based on the number of dump trucks loading and their soil-capacity, and the operating hours are two main aspects that must be considered for productivity monitoring (Kim and Chi 2020).

As it can be noted, traditional methods for productivity assessment at construction sites, despite being effective, are time-consuming and based on manual data collection and direct observation of activities on-site, which hampers the obtaining of reliable and up-to-date information of activities productivity.

\section{RESEARCH METHOD}

The research method of this study is a systematic literature review. The research questions to be answered are: What are the most used digital technologies for productivity monitoring in construction sites? How can these technologies help to monitor the productivity of construction activities? What are the main advantages and limitations of the technologies used?

The database used in the study were Scopus, ASCE Library, and Web of Science. The inclusion criteria established were: (1) Papers that have search terms at least in the title, abstract, or keywords; (2) Publications between 2010 and 2021; and (3) Articles published in journals. The exclusion criteria were: (1) Papers not focused on the engineering and construction area, and (2) Publications unrelated to the theme. The final sample consists of 35 selected papers, as shown in Table 1. The search on the database was performed by looking for the following terms:

- Construction AND (productivity OR "work sampling” OR "activity analysis" OR "value-adding time") AND (RFID OR UWB OR bluetooth OR sensors OR accelerometer OR "computer vision" OR "machine learning” OR "deep learning" OR “image processing” OR audio OR microphones). 
Table 1: Steps for the definition of the sample and number of papers found

\begin{tabular}{cccc}
\hline Steps & \multicolumn{3}{c}{ Data Base } \\
\cline { 2 - 4 } Search for terms & Scopus & ASCE & Web of Science \\
\hline Results of the search & $\begin{array}{c}\text { Title, abstract or } \\
\text { keywords }\end{array}$ & Full text & $\begin{array}{c}\text { Title, abstract or } \\
\text { keywords }\end{array}$ \\
Publications between 2010 and 2021 & 471 & 4916 & 282 \\
Publications on journals & 362 & 2684 & 241 \\
\hline
\end{tabular}

Remaining papers after removal by exclusion criteria: 35

The 35 selected papers are distributed into 13 journals (Figure 1a). The journal with the largest number of articles is Automation in Construction, with 13 publications, followed by the Journal of Computing in Civil Engineering appears with 7 publications, and the Journal of Construction Engineering and Management with 4 publications. Figure $1 \mathrm{~b}$ shows that there were variations in the number of publications over the years. The years with the largest number of publications were 2014 and 2019, with six papers on each. The papers were grouped according to the technologies used to collect and analyze productivity data. 16 publications $(45.7 \%$ of the sample) used sensor technologies, 16 $(45.7 \%)$ used technologies based on computer vision, and $3(8.6 \%)$ used technologies based on audio signals.

(a)

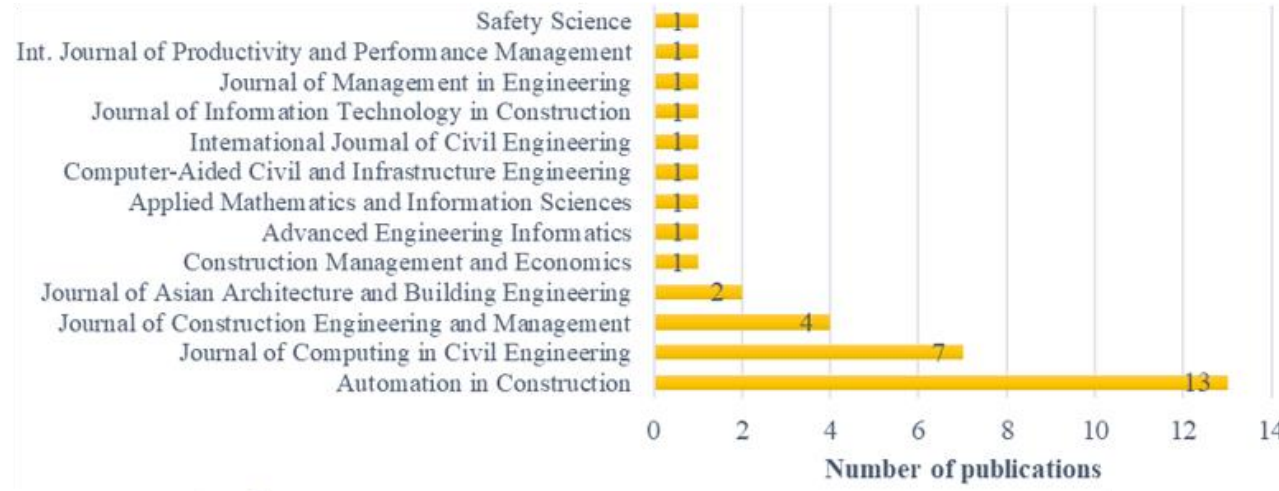

(b)

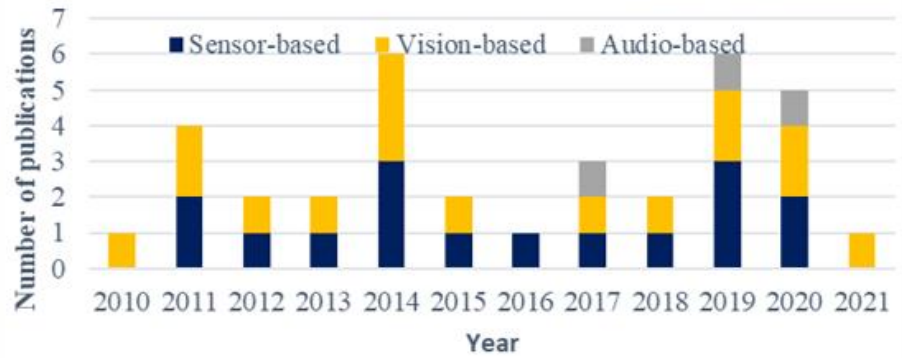

Figure 1: Distribution of publications (a) by journal, and (b) by year and type of technology used

\section{Methods USING COMPUTER Vision-BASEd TEChNOLOGIES}

Table 2 presents the 16 papers in the sample that use methods based on computer vision. Video-based activity analysis requires methods for detecting and tracking resources, and procedures for activity recognition (Liu and Golparvar-Fard 2015). Gong and Caldas (2010) present a video interpretation model that extracts productivity information from the video of a concrete column pour operation in real-time. Gong and Caldas (2011) extend this model to non-cyclic construction operations. Gong et al. (2011) classify the actions of workers and equipment on videos into categories that may be used for activity 
analysis. However, these authors pointed out challenges with gesture recognition on computer-based approaches.

According to Liu and Golparvar-Fard (2015), training and testing models used in computer-vision methods for activity analysis requires a large amount of empirical data which is not yet available to the research community. To address this limitation, these authors propose crowdsourcing the task of workface assessment from jobsite video streams with the assistance of a web-based marketplace platform. Despite that, applying crowdsourcing to workface assessment can be challenging due to the complexity of construction operations and the lack of formal taxonomy to describe activities (Liu and Golparvar-Fard 2015).

Table 2: Papers that use computer-vision-based technologies

\begin{tabular}{|c|c|c|}
\hline Authors & Subject monitored & Scope \\
\hline Calderon et al. (2021) & Excavators & Activity analysis \\
\hline Kim and Chi (2020) & $\begin{array}{l}\text { Excavators and dump trucks on } \\
\text { earthmoving activities }\end{array}$ & Activity analysis \\
\hline Roberts et al. (2020) & $\begin{array}{l}\text { Workers performing bricklaying } \\
\text { and plastering }\end{array}$ & Activity analysis \\
\hline Kim et al. (2019) & $\begin{array}{l}\text { Dump trucks on earthmoving } \\
\text { activities }\end{array}$ & $\begin{array}{c}\text { Measurement of work hours, cycles per } \\
\text { hour, and quantity installed }\end{array}$ \\
\hline $\begin{array}{l}\text { Roberts and Golparvar- } \\
\text { Fard (2019) }\end{array}$ & $\begin{array}{l}\text { Excavators and dump trucks on } \\
\text { earthmoving activities }\end{array}$ & Activity analysis \\
\hline Luo et al. (2018) & $\begin{array}{c}\text { Workers performing rebar and } \\
\text { formwork }\end{array}$ & Work sampling \\
\hline Bügler et al. (2017) & $\begin{array}{l}\text { Equipment on earthmoving } \\
\text { activities }\end{array}$ & $\begin{array}{l}\text { Activity analysis and measurement of } \\
\text { quantity installed and work hours }\end{array}$ \\
\hline $\begin{array}{l}\text { Liu and Golparvar-Fard } \\
\qquad(2015)\end{array}$ & $\begin{array}{l}\text { Workers and equipment on } \\
\text { concrete placement operations }\end{array}$ & Activity analysis \\
\hline $\begin{array}{l}\text { Khosrowpour et al. } \\
\qquad(2014)\end{array}$ & $\begin{array}{l}\text { Workers performing interior } \\
\text { drywall operations }\end{array}$ & Activity analysis \\
\hline Lee et al. (2014) & Workers performing formwork & $\begin{array}{c}\text { Measurement of quantity installed and } \\
\text { work hours }\end{array}$ \\
\hline Lee and Hong (2014) & Construction workers & Measurement of work hours \\
\hline $\begin{array}{l}\text { Ranaweera et al. } \\
\qquad(2013)\end{array}$ & Tunnel liners & $\begin{array}{l}\text { Measurement of tunnel construction } \\
\text { productivity in terms of shift production }\end{array}$ \\
\hline Bai et al. (2012) & Workers tying rebar & $\begin{array}{l}\text { Work sampling and analysis of } \\
\text { workers' efficiency }\end{array}$ \\
\hline $\begin{array}{l}\text { Gong and Caldas } \\
\qquad(2011)\end{array}$ & $\begin{array}{l}\text { Workers and equipment on } \\
\text { various construction activities }\end{array}$ & Activity analysis \\
\hline Gong et al. (2011) & $\begin{array}{c}\text { Backhoe and workers in formwork } \\
\text { activities }\end{array}$ & Activity analysis \\
\hline $\begin{array}{l}\text { Gong and Caldas } \\
(2010)\end{array}$ & $\begin{array}{l}\text { Concrete bucket on a concrete } \\
\text { column pour application }\end{array}$ & Activity analysis \\
\hline
\end{tabular}

Some papers focus on automated measurement of inputs and outputs to calculate the productivity of activities. Lee and Hong (2014) developed an image processing algorithm that analyzes and collects construction man-hours that can be used as the input factor for estimating productivity. Lee et al. (2014) developed algorithms for measuring installed work quantity and working hours of construction workers. The productivity data is linked with the 4D BIM model, which helps to predict construction scheduling for management purposes. Bügler et al. (2017) proposed a method for estimating the productivity of soil 
removal by combining photogrammetry to measure the volume of the excavated soil, and video analysis to generate statistics regarding the construction activities.

Pose estimation techniques, commonly used in research on construction worker ergonomics, have also gained prominence among productivity studies. Bai et al. (2012) developed a human pose analyzing algorithm that automatically determines the efficiency of work-face operations. Khosrowpour et al. (2014) and Roberts et al. (2020) used RGB visual data to detect and track workers' skeleton features to interpret and analyze their activities. Calderon et al. (2021) leveraged articulated 3D models of construction equipment in tandem with vision-based pose estimation methods to train and perform vision-based activity analysis.

The use of multiple cameras at different locations on-site can minimize problems related to occlusions on vision-based methods (Roberts and Golparvar-Fard 2019; Kim and Chi 2020). Surveillance cameras may not provide as detailed information as pose estimation methods, but can reduce costs with the use of cameras that already exist on construction sites. Bügler et al. (2017) and Kim et al. (2019) used surveillance cameras for productivity analysis of equipment on earthmoving activities, while Luo et al. (2018) used surveillance videos to track workers and conduct an automated work sampling.

One of the advantages of vision-based methods is that videos are understandable by any visually able person, provide detailed information, and allow reviews by managers away from the work sites (Liu and Golparvar-Fard 2015). Visual data contains information about not only the physical movements of workers and equipment, but also their visual features and spatial-contextual natures (Kim and Chi 2020). On the other hand, computer vision algorithms are sensitive to environmental factors such as occlusions, lighting, and illumination conditions (Cheng et al. 2017). Shaking of cameras caused by wind, and blur of images caused by rain, snow, and fog represent additional challenges for equipment and worker action recognition (Gong et al. 2011). Besides that, a single camera can only cover a limited field of view. To fully cover a large construction job site, it would be necessary to install multiple cameras in various locations (Cheng et al. 2017).

\section{Methods Using Sensor-Based TeChNOLOGIES}

Table 3 will present the 16 papers in the sample that use sensors to collect productivity data. The use of body-worn sensors such as accelerometer, gyroscope, and magnetometer that enable the measurement of workers' posture and motions has gained greater attention for construction activity monitoring. According to Joshua and Varghese (2011), accelerometers are resilient and robust in difficult conditions compared with image sensors, besides having a small size, good accuracy, and reasonable power consumption.

Another advantage is that they can be embedded in wristbands to classify activities performed with hands, such as masonry (Joshua and Varghese 2011; Ryu et al. 2019), ironwork, and carpentry (Joshua and Varghese 2014). Ryu et al. (2020) investigated whether journeymen adopt different work techniques that are safer and more efficient than those of apprentices using an accelerometer, a gyroscope, and a magnetometer, and found that journeymen have more advanced working methods concerning safety and productivity. Other studies used accelerometers embedded in smartphones to measure the operational efficiency of excavators (Ahn et al. 2015) and to detect activities of workers to obtain the proportion of time spent in each activity (Akhavian and Behzadan 2016).

Real-Time Location Sensors (RTLS) such as Radio Frequency Identification (RFID) and Ultra-Wideband (UWB) draw attention from researchers and practitioners because of their technological maturity, cost-efficient infrastructure, and ability to operate without line of sight (Cheng et al. 2017). Cheng et al. (2011) used UWB to analyze the time trajectories of workers and to perform automated work sampling. Costin et al. (2012) used 
RFID to track the efficiency of a buck hoist operator and material lift system for transportation. Zhao et al. (2019) applied Bluetooth Low Energy (BLE) to analyze the share of uninterrupted presence of workers in work locations, which is a necessary condition for value-added time, although not all time the workers spend in work locations is necessarily value-adding.

Table 3: Papers that use sensor-based technologies

\begin{tabular}{|c|c|c|c|}
\hline Authors & Sensors used & Subject monitored & Scope \\
\hline Lee et al. (2020) & $\begin{array}{l}\text { Accelerometer, } \\
\text { gyroscope, } \\
\text { magnetometer, and } \\
\text { a heart rate sensor }\end{array}$ & $\begin{array}{l}\text { Workers performing material } \\
\text { handling tasks }\end{array}$ & $\begin{array}{l}\text { Study of the influence of physical } \\
\text { strain and psychological stress } \\
\text { on workers' productivity }\end{array}$ \\
\hline Ryu et al. (2020) & $\begin{array}{l}\text { Accelerometer, } \\
\text { gyroscope, and } \\
\text { magnetometer }\end{array}$ & Masons & $\begin{array}{c}\text { Study of the influence of body } \\
\text { loads and level of experience on } \\
\text { productivity }\end{array}$ \\
\hline Jassmi et al. (2019) & $\begin{array}{l}\text { Sensors of blood } \\
\text { volume pulse, } \\
\text { respiration rate, } \\
\text { heart rate, etc. }\end{array}$ & $\begin{array}{l}\text { Workers on various } \\
\text { construction processes }\end{array}$ & $\begin{array}{c}\text { Study of the relationship between } \\
\text { workers' emotional status and } \\
\text { productivity }\end{array}$ \\
\hline Ryu et al. (2019) & Accelerometer & Masons & $\begin{array}{c}\text { Measurement of cycle time of } \\
\text { actions }\end{array}$ \\
\hline Zhao et al. (2019) & BLE & $\begin{array}{l}\text { Workers on various } \\
\text { construction processes }\end{array}$ & Work sampling \\
\hline $\begin{array}{l}\text { Lee and Migliaccio } \\
(2018)\end{array}$ & Heart rate sensor & $\begin{array}{c}\text { Workers installing a raised } \\
\text { deck }\end{array}$ & $\begin{array}{l}\text { Study of the relationship between } \\
\text { physical strain and productivity }\end{array}$ \\
\hline $\begin{array}{l}\text { Hwang and Lee } \\
\text { (2017) }\end{array}$ & Heart rate sensor & $\begin{array}{l}\text { Workers on various } \\
\text { construction processes }\end{array}$ & $\begin{array}{l}\text { Study of the inflluence of direct } \\
\text { and indirect work on workers' } \\
\text { physical demands }\end{array}$ \\
\hline $\begin{array}{l}\text { Akhavian and } \\
\text { Behzadan (2016) }\end{array}$ & $\begin{array}{l}\text { Accelerometer and } \\
\text { gyroscope }\end{array}$ & $\begin{array}{l}\text { Workers on various } \\
\text { construction processes }\end{array}$ & Work sampling \\
\hline Ahn et al. (2015) & Accelerometer & $\begin{array}{l}\text { Excavators performing utility } \\
\text { work, moving wastes, } \\
\text { demolishing, etc. }\end{array}$ & Work sampling \\
\hline $\begin{array}{l}\text { Ibrahim and Moselhi } \\
\qquad(2014)\end{array}$ & $\begin{array}{c}\text { GPS and } \\
\text { accelerometer }\end{array}$ & $\begin{array}{l}\text { Equipment on earthmoving } \\
\text { operations }\end{array}$ & $\begin{array}{c}\text { Measurement of quantity } \\
\text { installed, work hours, and cycle } \\
\text { time }\end{array}$ \\
\hline $\begin{array}{l}\text { Joshua and Varghese } \\
\text { (2014) }\end{array}$ & Accelerometer & Iron workers and carpenters & Work sampling \\
\hline Gatti et al. (2014) & $\begin{array}{l}\text { Heart rate and } \\
\text { breathing rate } \\
\text { sensor }\end{array}$ & $\begin{array}{c}\text { Workers assembling a raised } \\
\text { deck }\end{array}$ & $\begin{array}{l}\text { Study of the relationship between } \\
\text { productivity and physical strain }\end{array}$ \\
\hline Cheng et al. (2013) & $\begin{array}{l}\text { UWB and } \\
\text { accelerometer }\end{array}$ & $\begin{array}{l}\text { Workers assembling and } \\
\text { disassembling a raised deck } \\
\text { and building a wall }\end{array}$ & Work sampling \\
\hline Costin et al. (2012) & RFID & $\begin{array}{l}\text { Workers and elevator buck } \\
\text { hoists }\end{array}$ & $\begin{array}{l}\text { Recognition of non-value adding } \\
\text { time associated with the use of } \\
\text { the elevator }\end{array}$ \\
\hline Cheng et al. (2011) & UWB & $\begin{array}{l}\text { Workers, equipment and } \\
\text { material }\end{array}$ & Work sampling \\
\hline $\begin{array}{l}\text { Joshua and Varghese } \\
\qquad(2011)\end{array}$ & Accelerometer & $\begin{array}{l}\text { Workers performing masonry } \\
\text { activities }\end{array}$ & $\begin{array}{l}\text { Recognition of productive } \\
\text { activities }\end{array}$ \\
\hline
\end{tabular}

Although RTLS sensors can be useful for a variety of applications, without interpreting the activities and purely based on location information, deriving workface data is challenging (Liu and Golparvar-Fard 2015). Based on this issue, Cheng et al. (2013) 
attempt to automate the process of activity analysis by fusing information on body posture and the location of workers performing repeated activities. While accelerometers were mounted on a chest belt, UWB tags were placed on the participants' helmets for location tracking. In this method, the identification of direct work activity requires the participants to be present in the work zone and to have a high posture angle.

Other studies use biosensors in wearable devices to analyze factors that affect the productivity of construction workers. Heart rate (HR) is one of the physiological signals most used to study the influence of physical strain on productivity (Gatti et al. 2014, Hwang and Lee 2017; Lee and Migliaccio 2018). Jassmi et al. (2019) also used blood volume pulse, respiration rate, galvanic skin response, and skin temperature to assess the effect of the emotional status of workers on their productivity level. In the study of Lee et al. (2020), HR, activity levels, and sleep quality were monitored to examine how physical strain and psychological stress affect unskilled construction worker productivity and safety performance. Despite being promising, Joshua and Varghese (2011) highlight that the use of too many sensors may be uncomfortable for the subject and can interfere with normal or spontaneous activity.

\section{Methods USING AUdio-BASEd TEChNOLOGIES}

Table 4 presents the papers of the sample that use methods based on audio signals. Audio has been investigated by researchers as input data for recognizing activities of construction heavy equipment that generate distinct acoustic patterns while performing routine tasks (Cheng et al. 2019). Cheng et al. (2017) propose a system that records sounds generated by construction equipment by using commercially available microphones and classifies operations in productive or major activities and nonproductive or minor activities. Cheng et al. (2019) presented an audio-based activity recognition model tested under various hardware and software settings. Sabillon et al. (2020) proposed an audio-based system for estimating cycle times of construction equipment for multiple days of operation.

Table 4: Papers that use audio-based technologies

\begin{tabular}{|c|c|c|}
\hline Author & Equipment monitored & Scope \\
\hline Sabillon et al. (2020) & $\begin{array}{c}\text { Dozer, grader,backhoe excavator, and } \\
\text { excavator }\end{array}$ & $\begin{array}{c}\text { Measurement of cycles per } \\
\text { hour }\end{array}$ \\
\hline Cheng et al. (2019) & $\begin{array}{c}\text { Compactor, dozer, grader, excavator, and } \\
\text { mixer }\end{array}$ & $\begin{array}{c}\text { Measurement of cycles per } \\
\text { hour }\end{array}$ \\
\hline Cheng et al. (2017) & $\begin{array}{c}\text { Backhoe, wheelloader, mini excavator, } \\
\text { dozer, hydraulic hammer, dumper, breaking } \\
\text { up asphalt, and excavator }\end{array}$ & $\begin{array}{c}\text { Automated recognition of } \\
\text { productive and non-productive } \\
\text { activities }\end{array}$ \\
\hline
\end{tabular}

The application of audio signal processing techniques in the construction management area is still in the early stages of development (Cheng et al. 2019). Compared to visual and kinematic data, sound provides certain advantages: a single microphone can cover larger areas without the need to be directly attached to a machine, and the processing of audio files is computationally less expensive compared to processing images and video files (Sabillon et al. 2020). However, the existence of background noise might be a negative factor for the algorithms, and certain types of construction machinery do not generate distinct sound patterns during operation (Cheng et al. 2017; Sherafat et al. 2019). 


\section{DISCUSSION AND CONCLUSIONS}

A systematic literature review was carried out to identify and analyze the main existing methods in the literature for productivity monitoring on construction sites using digital technologies. The use of tools to automate techniques such as work sampling and activity analysis allows the identification of waste related to time spent on non-value-adding activities and enables the simplification of steps in a process, therefore being of great importance for lean construction research. However, this paper has the limitation of having analyzed specific categories, not presenting a broader approach on the topic.

Results show that technologies based on computer vision and sensors are the most used for productivity monitoring on construction sites. These technologies can automate data collection for the processes of work sampling and activity analysis, as well as to measure inputs and outputs, and monitor physical and emotional factors that can influence workers' productivity. Audio has been used for monitoring equipment productivity, especially for measuring cycle times. However, there are still few studies in this category.

Computer vision algorithms have made great advances in recent years, mainly with the use of deep learning techniques. Despite this fact, the detection of fine movements is still a challenge for vision-based methods. Pose estimation techniques, widely used in ergonomics studies, are capable of analyzing movements in a more detailed way. Due to their origin, pose estimation techniques have a great potential for studies of productivity monitoring integrated with ergonomics analysis. Regarding the use of sensors, further studies are needed to overcome the challenge of relating the worker's location to the type of work being performed, which could be done through the integration of RTLS with kinematic sensors. Studies using physiological signals have great potential to demonstrate the influence of stress and physical demand on workers' productivity.

Thus, as can be seen in Figure 2, there is an opportunity to combine the technologies of computer vision-based and sensor-based methods to provide evidence regarding the integrated management of productivity and safety and their impacts on the production process. This integration, despite being of great value, has been little explored in the literature.

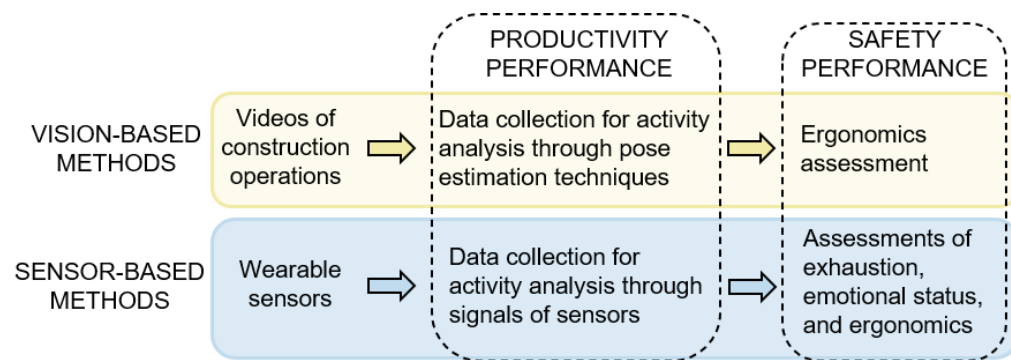

Figure 2: Workflow for integration of productivity and safety monitoring using digital technologies

\section{REFERENCES}

Ahn, C. R., S. Lee and F. Peña-Mora (2015). "Application of Low-Cost Accelerometers for Measuring the Operational Efficiency of a Construction Equipment Fleet." $J$. Comput. Civ. Eng. 29.

Akhavian, R. and A. H. Behzadan (2016). "Smartphone-based construction workers' activity recognition and classification " Autom. Constr. 71: 198-209.

Bai, Y., J. Huan and S. Kim (2012). "Measuring Bridge Construction Efficiency Using the Wireless Real-Time Video Monitoring System" J. Manage. Eng. 28: 120-126. 
Bügler, M., A. Borrmann, G. Ogunmakin and P. A. Vela (2017). "Fusion of Photogrammetry and Video Analysis for Productivity Assessment of Earthwork Processes" Comput. Aided Civ. Inf. Eng. 37: 107-123.

Calderon, W. T., D. Roberts and M. Golparvar-Fard (2021). "Synthesizing Pose Sequences from 3D Assets for Vision-Based Activity Analysis" J. Comput. Civ. Eng. 35(1).

Cheng, C.-F., A. Rashidi, M. A. Davenport and D. V. Anderson (2017). "Activity analysis of construction equipment using audio signals and support vector machines" Autom. Constr. 81: 240-253.

Cheng, C. F., A. Rashidi, M. A. Davenport and D. V. Anderson (2019). "Evaluation of Software and Hardware Settings for Audio-Based Analysis of Construction Operations" Int. J. Civ. Eng. 17: 1469-1480.

Cheng, T., J. Teizer, G. C. Migliaccio and U. C. Gatti (2013). "Automated task-level activity analysis through fusion of real time location sensors and worker's thoracic posture data" Autom. Constr. 29: 24-39.

Cheng, T., M. Venugopal, J. Teizer and P. A. Vela (2011). "Performance evaluation of ultra-wideband technology for construction resource location tracking in harsh environments" Autom. Constr. 20: 1173-1184.

Costin, A., N. Pradhananga and J. Teizer (2012). "Leveraging passive RFID technology for construction resource field mobility and status monitoring in a high-rise renovation project" Autom. Constr. 24: 1-15.

Gatti, U. C., G. C. Migliaccio, S. M. Bogus and S. Schneider (2014). "An exploratory study of the relationship between construction workforce physical strain and task level productivity" Const. Manag. Econ. 32: 548-564.

Gong, J. and C. H. Caldas (2010). "Computer Vision-Based Video Interpretation Model for Automated Productivity Analysis of Construction Operations." J. Comput. Civ. Eng. 24.

Gong, J. and C. H. Caldas (2011). "An object recognition, tracking, and contextual reasoning-based video interpretation method for rapid productivity analysis of construction operations." Autom. Constr. 20: 1211-1226.

Gong, J., C. H. Caldas and C. Gordon (2011). "Learning and classifying actions of construction workers and equipment $\mathrm{u}$ sing Bag-of-Video-Feature-Words and Bayesian network models" Adv. Eng. Inform. 25: 771-782.

Hwang, S. and S. Lee (2017). "Wristband-type wearable health devices to measure construction workers' physical demands " Autom. Constr. 83: 330-340.

Ibrahim, M. and O. Moselhi (2014). "Automated productivity assessment of earthmoving operations" J. Inf. Technol. Constr. 19: 169-184.

Jassmi, H. A., S. Ahmed, B. Philip, F. A. Mughairbi and M. A. Ahmad (2019). "Ehappiness physiological indicators of construction workers' productivity: A machine learning approach" J. Asian Archit. Build. Eng. 18: 517-526.

Joshua, L. and K. Varghese (2011). "Accelerometer-Based Activity Recognition in Construction." J. Comput. Civ. Eng. 25: 370-379.

Joshua, L. and K. Varghese (2014). "Automated recognition of construction labour activity using accelerometers in field situations" Int. J. Prod. Perform. Manag. 63: 841-862.

Khosrowpour, A., J. C. Niebles and M. Golparvar-Fard (2014). "Vision-based workface assessment using depth images for activity analysis of interior construction operations" Autom. Constr. 48: 74-87.

Kim, H., Y. Hama, W. Kim, S. Park and H. Kim (2019). "Vision-based nonintrusive context documentation for earthmoving productivity simulation" Autom. Constr. 102. 
Kim, J. and S. Chi (2020). "Multi-camera vision-based productivity monitoring of earthmoving o perations" Autom. Constr. 112.

Koskela, L. (1992). Application of the New Production Philosophy to Construction. Finland.

Lee, C., J. Som and S. Lee (2014). "A System Model for Analyzing and Accumulating Construction Work Crew's Productivity Data Using Image Processing Technologies" J. Asian Archit. Build. Eng. 13: 547-554.

Lee, S. and M. Hong (2014). "Implementation of Man-Hours Measurement System for Construction Work Crews by Image Processing Technology" Appl. Math. Inf. Sci. 8: 1287-1293.

Lee, W., G. C. Migliaccio, K.-Y. Lin and E. Y. W. Seto (2020). "Workforce development: understanding task-level job demands-resources, burnout, and performance in unskilled construction workers" Saf. Sci. 123.

Liou, F.-S. and J. P. Borcherdin (1986). "Work sampling can predict unit rate productivity." J. Constr. Eng. Manage. 112: 90-103.

Liu, K. and M. Golparvar-Fard (2015). "Crowdsourcing Construction Activity Analysis from Jobsite Video Streams" J. Constr. Eng. Manage. 141.

Luo, X., H. Li, D. Cao, Y. Yu, X. Yang and T. Huang (2018). "Towards efficient and objective work sampling: Recognizing workers' activities in site surveillance videos with two-stream convolutional networks." Autom. Constr. 94: 360-370.

Ranaweera, K., J. Ruwanpura and S. Fernando (2013). "Automated Real-Time Monitoring System to Measure Shift Production of Tunnel Construction Projects." $J$. Comput. Civ. Eng. 27: 68-77.

Ribeirinho, M. J., J. Mischke, G. Strube, E. Sjödin, J. L. Blanco, R. Palter, J. Biörck, D. Rockhill and T. Andersson (2020). The next normal in construction McKinsey \& Company.

Roberts, D., W. T. Calderon, S. Tang and M. Golparvar-Fard (2020). "Vision-Based Construction Worker Activity Analysis Informed by Body Posture " J. Comput. Civ. Eng. 34.

Roberts, D. and M. Golparvar-Fard (2019). "End-to-end vision-based detection, tracking and activity analysis of earthmoving equipment filmed at ground level" Autom. Constr. 105.

Ryu, J., A. Alwasel, C. T. Haas and E. Abdel-Rahman (2020). "Analysis of Relationships between Body Load and Training, Work Methods, and Work Rate: Overcoming the Novice Mason's Risk Hump " J. Constr. Eng. Manage. 146.

Ryu, J., J. Seo, H. Jebelli and S. Lee (2019). "Automated Action Recognition Using an Accelerometer-Embedded Wristband-Type Activity Tracker" J. Constr. Eng. Manage. 145.

Sabillon, C., A. Rashidi, B. Samanta, M. A. Davenport and D. V. Anderson (2020). "Audio-Based Bayesian Model for Productivity Estimation of Cyclic Construction Activities " J. Comput. Civ. Eng. 34.

Thomas, H. R., W. F. Maloney, R. M. W. Horner, G. R. Smith, V. K. Handa and S. R. Sanders (1990). "Modeling construction labor productivity." J. Constr. Eng. Manage. 116: 705-726.

Tortorella, G. L., R. Giglio and D. H. Van Dun (2019). "Industry 4.0 adoption as a moderator of the impact of lean production practices on operational performance improvement." Int. J. Oper. Prod. Manag. 39.

Zhao, J., O. Seppänen, A. Peltokorpi, B. Badihi and H. Olivieri (2019). "Real-time resource tracking for analyzing value-adding time in construction." Autom. Constr. 104: 52-65. 